\title{
Tema: Protestantismen til debat
}

Dansk Teologisk Tidsskrifts redaktion har besluttet for fremtiden regelmæssigt at bringe temanumre. Dette er det første af dem. Hensigten er at supplere paletten af enkeltartikler, der tilsammen giver overblik over den aktuelle forskning, med artikler, der fokuserer på den samme problematik.

Bidragene til første temanummer er reviderede versioner af oplæg holdt ved et seminar med titlen "Reformation og deformation - protestantismen til debat", der fandt sted den 7. maj 2010 på Det Teologiske Fakultet, Aarhus Universitet. Seminaret var på samme tid en del af arbejdet i forskergruppen "Reformatorisk teologi", der er hjemhørende samme sted, afholdt i anledning af professor dr. theol. Peter Widmanns 70 års fødselsdag.

Der er mange gode grunde til at tage protestantismebegrebet op til debat. Protestantismen forandrer sig. Reformationen er ikke kun en transformativ kraft, men transformeres også selv. Udviklingen $i$ reformatorisk teologi er også udviklingen af reformatorisk teologi. Nogle vil sågar mene, at der er i denne udvikling også er tendenser til afvikling af reformatorisk teologi.

Peter Widmanns indledende bidrag "Reformation og deformation" tager udgangspunkt i samtidens tendenser til at give spørgsmålet om religionens fremtid et førmoderne svar. Dette bliver anledningen til at diskutere Barths angreb på såvel den neo-protestantistiske syntese af modernitet og kristendom, som på den konservativt pietistiske modreaktion på denne syntese. Heroverfor sætter Barth den reformatoriske afgørelse, der falder i lydighed mod åbenbaringens ord, forstået som det ord, der bringer alle andre ord til tavshed.

Bag Widmanns interesse for en reformulering af det protestantiske ligger Paul Tillichs stikordsagtige sammenfatning af den teologi, der i det 20. århundrede orienterede sig efter reformationens centrale indsigter, i begrebet om "det protestantiske princip". Det protestantiske blev her forstået som modsætningen til såvel middelalderens store synteser som de moderne forsøg på at indføje kristen tro i en syntese med kulturen: Mellem det syndige menneske og den retfærdiggørende Gud kan der ikke etableres nogen syntese, var påstanden. Reformationen var derfor det nødvendige værn mod kristendommens deformation. Det rejser spørgsmålet, om reformationen er nået langt nok eller om der stadig er deformationer at afværge? Eller har refor- 
mationen selv bidraget til deformationsprocessen? Widmann afslutter sin artikel med en diskussion af Barths bestemmelse af det reformatoriske, som må afbalanceres, men ikke glemmes, hvis det reformatoriske vedblivende skal være en teologisk udfordring.

Niels Henrik Gregersen afviser i sit bidrag forsøget på at sammenfatte luthersk teologi under et generelt protestantisk princip. Reformationens anliggende i dens lutherske udformning kan ikke defineres ud fra anden-ordens principper uden at foretage en trivialisering. Det reformatoriske anliggende baserer sig derimod - også hos Luther - på kristendommens primære livsytringer (dåb, nadver, bøn, lovsang, skriftlæsning etc.). Derfor må de såkaldte reformatoriske eksklusiv-partikler, solo Christo, sola fide, etc. i stedet forstås som "inklusiv-partikler", der altid bringer mere med sig. Derfor når Luthersk teologi ikke sit mål gennem principialisering, men først når den får kød og blod og samtidig indeholder en forestillingen om menneskelig participation i det guddommelige.

Werner Jeanrond overvejer i sit bidrag det protestantiske princips potentiale for den teologiske behandling af spørgsmålet om kirkelig fornyelse i en såvel tværkonfessionel som en tværreligiøs sammenhæng. Potentialet hænger for Jeanrond tæt sammen med det forhold, der hos Paul Tillich er mellem det protestantiske princip og den "katolske substans", men som han ikke finder varetaget hos Barth. I sammenhæng med en forståelse af den "katolske substans" kan det protestantiske princip derimod angive en retning for fremtidens teologi.

George Pattison inddrager Kierkegaards kirkestorm i sin behandling af det protestantiske, især den betydning kirkestormen havde for det 20. århundredes religionsløse eller sekulære kristendom. Kierkegaards afvisning af den moderne verdensforståelse, der sine steder får næsten gnostiske træk, behøver ikke blive gentaget for at videreføre den blivende pointe, at det reformatoriske i bedste fald forbliver problematisk, tvetydigt og en vedvarende udfordring, hvis det tages alvorligt.

Til slut bringes en artikel uden for temaet, nemlig Kjeld Slot Nielsens diskussion af navnlig Jakob Wolfs behandling af teodicé-spørgsmålet. 